\title{
Confiscation and Criminal Assets Recovery-Review of Bosnian Law
}

\author{
Anton Girginov ${ }^{1,2}$ \\ ${ }^{1}$ University of Plovdiv, Plovdiv, Bulgaria \\ ${ }^{2}$ Public Prosecutor's Office of Bosnia and Herzegovina, Sarajevo, Bosnia and Herzegovina \\ Email:girginov@hotmail.com
}

How to cite this paper: Girginov, A. (2017). Confiscation and Criminal Assets Recovery-Review of Bosnian Law. Beijing Law Review, 8, 252-270.

https://doi.org/10.4236/blr.2017.83015

Received: June 10, 2017

Accepted: August 8, 2017

Published: August 11, 2017

Copyright (c) 2017 by author and Scientific Research Publishing Inc. This work is licensed under the Creative Commons Attribution International License (CC BY 4.0).

http://creativecommons.org/licenses/by/4.0/

\section{(c) (†) Open Access}

\begin{abstract}
This paper deals with the legal frameworks in Bosnia and Herzegovina $\{\mathrm{BiH}\}$ for confiscation and criminal assets recovery. It contains proposals for improvement of local laws regulating domestic activities and international judicial cooperation for confiscation and criminal assets recovery. The presentation is in pursuit of two goals: increase the efficiency of confiscation in $\mathrm{BiH}$ and intensify international legal contacts of $\mathrm{BiH}$ with other countries for the purpose of depriving offenders of their wealth and deter them from committing new crimes. Several legislative proposals are made, namely: abandon the crime-related confiscation and adopt the unexplained wealth confiscation, create two domestic rules: for international sharing of crimeconditioned assets and for confiscation on foreign requests of assets when the conditioning crime is beyond the applicability of the local criminal law. Also, it is argued that $\mathrm{BiH}$ is in need of submitting a declaration to European Convention on Mutual Assistance in Criminal Matters and the Second Additional Protocol thereto. This declaration should state that $\mathrm{BiH}$ accepts letters rogatory from Parties to the Convention through the EUROJUST channel.
\end{abstract}

\section{Keywords}

Confiscation, Criminal Assets Recovery, Unexplained Wealth, International Legal Assistance

\section{Introduction: Multiplicity of Legal Frameworks for Confiscation and Criminal Assets Recovery}

Bosnia and Herzegovina $\{\mathrm{BiH}\}$ is a complex country in Southeastern Europe located on the Balkan Peninsula. It includes 4 components, each with its own Criminal Code, Criminal Procedure Code and other laws as well. These four 
components are: the State Level, two entities (RepublikaSrpska, the Federation of $\mathrm{BiH}$ ) and Brcko District ${ }^{1}$. Each component has also its own legal framework for confiscation and criminal assets recovery. Everywhere, however, confiscation is a crime-related security measure. To open the way to it, there must be not only a crime proven by a guilty verdict but also a connection of the targeted assets with some criminal activity as well. Otherwise, the assets are not confiscable.

Republika Srpska $\{R S\}$ is leading in the creation of the legal framework for confiscation and criminal assets recovery in $\mathrm{BiH}$. It has been applying its own special Criminal Assets Recovery Act since 2010. RS was the first in $\mathrm{BiH}$ to introduce the so-called extended confiscation. Recently, the other entity ${ }^{2}$, the Federation of $\mathrm{BiH}$ also adopted its own special Law Forfeiture of Criminal Proceeds [Official Gazette of the Federation of $\mathrm{BiH} 71 / 14$ of 3 Sept. 2014, entry into force on 12 March 2015]. The provisions of this Law are similar to some extent.

At this point, neither the State level nor the Brcko District has any special law in force on criminal assets recovery ${ }^{3}$. They rely on the application of their Criminal Codes $\{\mathrm{CC}-\mathrm{s}\}$ and the provisions on confiscation, in particular, which have been modified to also materialize the idea of extended confiscation.

\section{From Extended Confiscation to Confiscation of Unexplained Wealth}

1) It must be taken into consideration that the RS extended confiscation, like any other security measure of crime-related confiscation, is also conditioned on commission of a crime as far as the owner of the property liable (subject) to confiscation shall be found guilty of some serious crime listed in the applicable national law ${ }^{4}$ : CC or Criminal Assets Recovery Act, if any. In any case, it is the owner's criminal assets which are liable to confiscation. Article 3(1), "b" of the RS Criminal Assets Recovery Act $\{\mathrm{CARA}\}$ defines them. It reads as follows: "The criminal assets are the property of the offender, property owner, obtained prior to initiation of criminal proceedings defined in the Article 2 of this Act, that are in obvious discrepancy with his reported incomes, reported incomes are all the available financial resources of the property owner for which it is possible to determine legality of its the acquisition".

However, there is another provision in CARA which brings some restriction to the confiscation of the non-reported (and therefore, illegal) incomes which are in obvious discrepancy with the reported ones. This is the provision of Article 3(1), "a" of CARA. It reads: "Assets are collection of property rights and obligations of the holder of those rights over the real estate and chattels. A property is also considered the profit or any other gain which has been obtained directly

${ }^{1}$ See Miljko (2006), p. 3.

${ }^{2} \mathrm{BiH}$ consists of two entities-Federation of $\mathrm{BiH}$ and RS. Brcko District is also included in $\mathrm{BiH}$ as a separate territorial formation.

${ }^{3}$ However, Brcko District has such a draft law.

${ }^{4}$ In some cases confiscation might be at the expense of some third connected persons (see Article 3, "c", " $f$ " and "g" of CARA and Article 4, "d" of the Federation of BiH Law on Forfeiture of Criminal Proceeds) but this issue is beyond the subject of this paper. 
or indirectly from the crime..."

This crime is obviously not the one for which the property owner was found guilty; his/her assets deriving from the crime for which s/he was found guilty are, in any case, confiscable under CC, including indirect and intermingled assets ${ }^{5}$. Therefore, it makes sense only if Article 3(1), "a" of CARA envisages one or more different crimes which produced other illegal assets. Such assets may also be confiscated. However, under Article 3(1), it is not sufficient for their confiscation that they are just non-reported (illegal). It is also necessary the assets may come from some criminal activity. Given the unconditionally of the legal text, this must be proven beyond any reasonable doubt.

The $\mathrm{BiH}$ State law also goes into the same direction but is less requiring and eventually more realistic on the issue. Article $110 \mathrm{a}(1)$ of the $\mathrm{BiH} \mathrm{CC}$ requires evidence that the property should originate from some crime(s). It reads that there must be "sufficient evidence to reasonably believe that the property gain is of criminal origin" .

Hence, both Article 3(1) of CARA and Article 110a(1) of the BiH CC provide a strong argument to maintain that the words "gain which has been obtained directly or indirectly from the crime" constitute another, a separate criterion for confiscation. As a result, the convicted owner may successfully argue, given the criminal law presumption of innocence, that a great part of his/her disproportionate property derived from violations of law which do not constitute crimes. This is why this part of his/her illegal income shall not be confiscated.

Such a difficulty resulting from the words "gain which has been obtained directly or indirectly from the crime" is hardly necessary. The confiscation of illegal property (the non-reported income), not originating from the crime for which the owner was found guilty, is not any punishment. It is a security measure. As such [often called FORFEITURE as well ${ }^{7}$ ], this measure is not turned to the past, namely: to crimes that may have already been committed. Given its nature, this confiscation addresses the present. It is designed to tackle some existing danger. Specifically, the confiscation in question tackles the danger from serious crimi-

${ }^{5}$ Article 94 of the CC of RS provide that no one shall be allowed to retain material gain acquired by the perpetration of a criminal offence, and material gain shall be confiscated by the court decision that established the perpetration of a criminal offence. The confiscation of all assets from such criminal offences, incl. indirect and intermingled assets, had been confirmed in practice by judgments in a number of cases in RS.See point 64 of the C198-COP (2015) RASS6. CONFERENCE OF THE PARTIES, Council of Europe Convention on Laundering, Search, Seizure and Confiscation of the Proceeds from Crime and on the Financing of Terrorism (CETS no $\left.{ }^{\circ} 198\right)$. Assessment Report of the Conference of the Parties to CETS no ${ }^{\circ}$ 198. BOSNIA AND HERZEGOVINA, CoE, Strasbourg, 6 November 2015, p. 17.

${ }^{6}$ Such a causal connection is required in the Federation of Bosnia and Herzegovina given Articles $4(1,2)$ and $6(2,3)$ of its Law on Forfeiture of Criminal Proceeds. Besides, this connection is expressly required in the common Article 114a of the CC of the Federation and the CC of Brcko District. This common Article reads: "the court can also decide ... to order confiscation of materiai gain for which the prosecutor provides sufficient evidence that there is reasonable suspicion that it was acquired through execution of these criminal offences...". Finally, Article 98A(1) of the CC of Macedonia also postulates that confiscation takes place, if "the assets that exceed the legal income or the perpetrator have resulted from such a criminal offence".

${ }^{7}$ This is because it constitutes a security measure; the word confiscation per se is used for the respective punishment, especially in countries where both exist, such as Bulgaria. Ненов (1992), с. 274. 
nal offenders (found guilty of one or more serious crimes expressly mentioned in law). The danger is materialized in the presumable possibility that the convicted offenders may use their illegal property, including the part not deriving from their ascertained crimes, for further criminal activities ${ }^{8}$. In any case, the use of this illegal property for criminal purposes is not less probable than the use by the convicts for same purposes of their illegal property originating from the crimes for which they were found guilty or from any other crimes they might have committed in the past.

Hence, any link with any such imaginary crimes for which the owner of the illegal property was never found guilty is irrelevant to substantiate confiscation as a security (preventive) measure. Per argumentum a fortiori, there is no reason to presume that the owner has also committed crimes for which s/he was not found guilty in order to justify the confiscation of the illegal property which does not derive from the crime(s) for which s/he was found guilty. Any such suspicion thatmaterial benefit derived from past criminal activities, which were never proven actually, solely constitutes useless, even counterproductive disregard of the criminal law principle of the presumption of innocence.

Therefore, it should be sufficient to ascertain the illegality of the convicted owner's property which is in obvious discrepancy with his/her legal incomes: on the grounds that s/he cannot explain the legality of its acquisition. It would not be necessary to have any evidence for its criminal origin, let alone prove it.

This is, actually, confiscation based on the "UNEXPLAINED WEALTH THEORY". It is a very efficient one in the fight against organized and other major crime. Its advantages are the possibility for a quicker reaction by the state authorities, better possibilities for more efficient preservation, significantly shorter terms for judicial procedures, as well as independence of the procedures from the outcome of criminal proceedings.

On the one hand, this confiscation, unlike "pure" civil forfeiture", still needs a criminal judgment, in general, as a legal ground. However, on the other hand, unlike the extended confiscation, this is a confiscation of all illegal (unexplained) property which does not derive from the crime(s) established by the judgment. This means that the subject of confiscation does include only the assets determined to originate from the specific criminal offence proven in court but also those assets of the convict that $s /$ he was unable to prove to have been

\footnotetext{
${ }^{8}$ ccording to the European Court of Human Rights, such confiscation measures "sought to prevent theunlawful use, in a way dangerous to society, of possessions whose lawful origin has not been established" [ECtHR, M. v. Italy, $\mathrm{N}^{\circ} 12,386 / 86$ ]. In relation to the use of a presumption about future behavior, the Court confirmed that "the Convention obviously does not prohibit such presumptions in principle".

${ }^{9}$ In USA, civil forfeiture lawsuits are filed against the property, not its owners. There is no need for a criminal conviction. In the majority of cases, there may not even be any criminal charges filed against the owner of the property. The only requirement needed to give the government the right to seize a person's property is the probability that the property was gained through illegal means. This piece of information is taken from

http://www.assetforfeituredefender.com/resources/criminal-vs-civil-forfeiture, accessed on 17 April 2017.
} 
obtained legally. Finally, unlike confiscation which is foreseen as a punishment ${ }^{10}$, this extended confiscation never concerns assets of lawful origin.

\begin{tabular}{|c|c|c|}
\hline Criteria for Comparison & $\begin{array}{c}\text { Crime-related } \\
\text { Theory }\end{array}$ & $\begin{array}{l}\text { Unexplained } \\
\text { Wealth Theory }\end{array}$ \\
\hline $\begin{array}{l}\text { Shall the object of confiscation be the whole property whose } \\
\text { legality is not proven (except for non-confiscable items) rather } \\
\text { than only property originating from crime? }\end{array}$ & NO & YES \\
\hline $\begin{array}{l}\text { Do the authorities carry the burden of proof; do they need to } \\
\text { establish a link between the property to be confiscated and the } \\
\text { committed crime? }\end{array}$ & YES & NO \\
\hline $\begin{array}{l}\text { Is it appropriate to install a separate confiscation } \\
\text { procedure, apart from the corresponding criminal proceedings? }\end{array}$ & NO & YES \\
\hline
\end{tabular}

2) The BiH State law also provides for extended confiscation of convict's assets. However, the $\mathrm{BiH}$ State law requires only a serious suspicion that they originate from some serious crime that the owner has committed. Article 110a(1) of the BiH CC postulates that there must be "sufficient evidence to reasonably believe that the property gain is of criminal origin" ${ }^{\text {"11 }}$. There is no legal requirement in the text of this provision, however, that the property of the convict shall pass any specific threshold, such as "obvious discrepancy" to legal incomes, to become confiscable. The Paragraph in question reads as follows:

"In cases of criminal proceedings for criminal offences referred to in chapters $X V I I, X V I I I, X I X, X X I, X X I A$ and XXII of this Code, the court can also decide, on the basis of Article 110 paragraph (2), to order confiscation of property gain, income, profit or other form of benefit from the property gain for which the prosecutor provides sufficient evidence that there is reasonable suspicion that it was acquired through execution of these criminal offences, and the accused person did not provide evidence to prove that the property gain, income, profit or other form of benefit from the property gain was acquired legally".

Probably, the RS legislative solution is preferable. It is fairer, simpler and closer to the unexplained wealth confiscation theory which is the recommendable one, virtually. The RS law clearly states that subject of extended confiscation

\footnotetext{
${ }^{10}$ e.g. in Bulgaria whose CC reads: "Article 44 . Confiscation shall be compulsory appropriation without compensation of property in favour of the state, of assets belonging to the convict or a part thereof, of specified pieces of property of the culprit, or of parts of such pieces of property. Article 45. 1) Confiscation shall not be ordered if the culprit does not possess available property which could be subject to such punishment. 2) Subject to confiscation may not be the objects needed by the convict and his family for personal and family use, the objects necessary for the exercise of his vocation specified in a list approved by the Council of Ministers, as well as means for support of his family for one year".

${ }^{11}$ Such a causal connection is required in the Federation of Bosnia and Herzegovina given Articles $4(1,2)$ and $6(2,3)$ of its Law on Forfeiture of Criminal Proceeds. Besides, this connection is expressly required in the common Article 114a of the CC of the Federation and the CC of Brcko District. This common Article reads: "the court can also decide ... to order confiscation of materiai gain for which the prosecutor provides sufficient evidence that there is reasonable suspicion that it was acquired through execution of these criminal offences...". Finally, Article 98A(1) of the CC of Macedonia also postulates that confiscation takes place if "the assets that exceed the legal income or the perpetrator have resulted from such a criminal offence".
} 
might only be illegal property in obvious discrepancy with the legal incomes (Article 3.1, "b" of CARA), while the other laws in BiH make it possible to confiscate any illegal property. It follows that the RS law does not overburden the judiciary with petty cases either.

No doubt, only this illegal property of the convict, not originating from the crime that s/he was found guilty of, which is in obvious discrepancy with his/her legal incomes, must be the subject of confiscation proceedings. At the same time, it should not be necessary under any law in $\mathrm{BiH}$ to find evidence for the criminal origin of the property, let alone prove it. Moreover, in contrast to the Romanian legislative solution, for example ${ }^{12}$, the confiscable property should not need to have any link with the crime its owner has been found guilty of. Once no such link is required, respective laws in $\mathrm{BiH}$ would be in full compliance with the efficient UNEXPLAINED WEALTH THEORY. It is noteworthy, in the end, that this theory is successfully implemented through the legislation of some EU countries, such as: Bulgaria ${ }^{13}$ and Italy ${ }^{14}$.

3) It is worth mentioning that not only EU countries have accepted the unexplainable wealth theory. Montenegro, the neighbor of $\mathrm{BiH}$, also implements this theory. This conclusion comes from the text of Article 8 [Material Benefit Seizure from the Perpetrator] ofthe Montenegrin Law on Seizure and Confiscation of Material Benefit Derived from Criminal Activity.

It is true that the causal link of the forfeitable convict's property with suspected criminal activities appears in the text of the Article, together with the obvious (manifest) disproportionality of this property of the convict to his/her lawful income. Nevertheless, this link does not constitute any separate requirement for confiscation. Actually, it solely clarifies why the convict's property has become manifestly disproportional to his/her lawful income. The explanation is that this property has become manifestly disproportional because it was derived from criminal activities. Pursuant to Paragraph 3 of the aforementioned Article,

\footnotetext{
${ }^{12}$ Article 112(1) of the Romanian CC reads: "The following shall be subject to special confiscation: 1) assets produced by perpetrating any offense stipulated by criminal law, 2) assets that were used in any way, or intended to be used to commit an offense set forth by criminal law, if they belong to the offender or to another person who knew the purpose of their use, 3) assets used immediately after the commission of the offense to ensure the perpetrator's escape or the retention of use or proceeds obtained, if they belong to the offender or to another person who knew the purpose of their use, 4) assets given to bring about the commission of an offense set forth by criminal law or to reward the perpetrator, 5) assets acquired by perpetrating any offense stipulated by criminal law...".

${ }^{13}$ Its law does not require connection of the property subject to confiscation with any criminal activity. It is sufficient for the confiscation that the legal origin of the property has not been provenArticle 1 of the Bulgarian 2012 Law on Forfeiture of Illegally Acquired Assets. Pursuant to Article 21 of the Law, the procedure is launched, if a founded suspicion that significant discrepancy [in practice: 250,000 leva $(€ 125,000)]$ between the legal income and the expenditure of the person exists.

${ }^{14}$ See Article 12-sexies of the Italian Law no. 356 of 1992, as it was modified by the Law no. 501 of 1994 ("Urgent provisions in relation to the confiscation of illicit assets"). It imposes compulsory confiscation of all "unjustified" assets. The essential condition for their confiscation is that the owner has been found guilty and was irrevocably sentenced for any one of the crimes specifically indicated by the Law. Additionally, the Law requires also: 1) that the assets are disproportionate to the convict's official income or activity and 2) that the convict cannot provide satisfactory proof of the legal origin of the assets. Turone (2006), p. 48.
} 
"Well-founded suspicion that material benefit was derived from criminal activities exists if the property of the perpetrator ... is manifestly disproportionate to his lawful income". Per argumentum a contrario, if the property is not manifestly disproportional to the lawful income, it is not linkable to any criminal activities at all. So the causal link of the property with criminal activities is just an inevitable derivative of its manifested (obvious) disproportionality. No separate evidence is necessary for this causal link. This is why the link in question cannot be regarded as another legal requirement for the confiscation of the property. Despite being mentioned in the law, this link cannot amount to anything more than an explanation as to why the property is manifestly disproportional and shall be confiscated.

However, regardless of any explanations, the manifested (obvious) disproportionality of unexplainable wealth alone is sufficient for its confiscation. This makes confiscation under Montenegrin law based, actually, on the Unexplained Wealth theory. It is not crime-related at all because the causal link with criminal activities is not mentioned in law as a requirement for confiscation.

After all, if even "pure" civil forfeiture, which does not need any criminal judgment at all, has been accepted in some countries (such as: Australia, Columbia, USA, etc.), it would be feasible, per argumentum a fortiori, to introduce confiscation of unexplained wealth, as it needs a criminal judgment for the conditioning crime.

\section{The Rules on International Cooperation and Their Improvement}

1) Pursuant to Article 14.1 of the UN Convention against Transnational Organized Crime $\{$ UNCATOC\}, Article 57.1 of the UN Convention against Corruption $\{\mathrm{UNCAC}\}$ and Article 15 of the European Convention on Laundering, Search, Seizure and Confiscation of the Proceeds from Crime, countries executing foreign requests for confiscation of assets found in their territories, dispose of the assets in accordance with their national laws. Most often, requested countries make laws to benefit themselves. Their laws postulate that, in general, confiscated assets shall become their property. However, requested countries do not necessarily retain all assets. Options of their redistribution exist. In particular, apart from returning any seized item to its initial possessor if $\mathrm{s} / \mathrm{he}$ has acted in good faith (Articles 12.8 and 14.2.ii of UNCATOC and Articles 31.9 and 57.1, 3 of UNCAC), the confiscated property may also be shared with the informer of its whereabouts as well.

Legal regulation of such sharing of assets is recommendable. It would be appropriate having a rule in law on asset sharing between the lawful owner (mostly, the confiscating country) and the one who found and reported the assets, incl. the foreign country which by requesting the confiscation of the assets contributed to the successful result.

The basic considerations for having such a specific rule in favor of the requesting country are similar to those arguments which support benefiting finan- 
cially under any national obligation law persons who have found and returned a lost item or who have reported its whereabouts, at least. Essentially, the arguments are: to make everyone interested in providing such cooperation.

Thus, the person who returns a lost item is awarded $10 \%$ of its value, pursuant to the RS Real Rights Law, or even up to $20 \%$ of the lost item's value, pursuant to the Armenian Civil Code, for example. Some similar share might be foreseen in favor of anyone, incl. foreign countries which help $\mathrm{BiH}$ to find in its territory and confiscate property which eventually would belong to its budget.

Also, international sharing of assets is widely recommended to stimulate execution of confiscation requests from foreign countries ${ }^{15}$. Pursuant to Point 38(2) of the Financial Action Task Force 40 Recommendations of October 2003-4, "there should also be arrangements for coordinating seizure and confiscation proceedings, which may include the sharing of confiscated assets".

At this point, bilateral agreements are the reliable legal instruments to achieve international asset sharing. It is noteworthy that asset sharing arrangements between countries find support also in multilateral UN instruments-Article 14(3)(b) of the UNCATOC. However, no multilateral convention expressly requires sharing of confiscated assets. Moreover, one can hardly expect any multilateral solution in the near future. According to a reliable source, several years ago Iraq carried out consultations for a Protocol on international asset sharing to the UNCAC. However, the Iraqi initiative did not yield any positive result ${ }^{16}$.

The issue of asset sharing has been solved to some extent in the EU by the Framework Decision 2006/783/JHA of 6 October 2006 on theapplication of the principle of mutual recognitionto confiscation orders. Pursuant to Article 16, when money has been obtained through theexecution of a confiscation order, it remains in full with the executing (requested) country, if the amount is 10,000 euros or less. Otherwise, 50 per cent of the amount obtained is transferred to the issuing (requesting) country. This Framework Decision is liable to legislative implementation by EU countries but it is also an example worth following by the authorities in $\mathrm{BiH}$ as well.

A rule on international asset sharing would be particularly advantageous in regard to foreign countries with which $\mathrm{BiH}$ has no international agreement containing a provision on sharing of assets. As $\mathrm{BiH}$ is not likely to have such agreements with all foreign countries, it must rely on domestic rules of other countries on international asset sharing to benefit from it. Necessarily, $\mathrm{BiH}$ must develop, in turn, its own provisions on such asset sharing to ensure reciprocity.

Lastly, no international asset sharing action excludes any domestic asset sharing, incl. for the benefit of contributing state agencies in the country. On the contrary, international asset sharing might be complementary to such domestic asset sharing in pursuit of the goal to be most efficient.

\footnotetext{
${ }^{15}$ Asset sharing arrangements between requesting and requested countries find support in multilateral instruments, such as the UNCATOC-Article 14 (3)(b).

${ }^{16}$ This information was received from the Iraqi authorities by the author of the current paper who worked in Baghdad (2012-2013) as the Head of the Judiciary Team of the EUJUSTLEX for Iraq.
} 
Either way, creating domestic rules on international assets sharing is necessary. As competent public officials are in need of a law authorizing confiscation, they also need specific provisions (international or domestic, at least) authorizing any following international asset sharing as well ${ }^{17}$. Otherwise, without a legal basis, no one can give any part of the confiscated property to requesting/informing countries in order to financially stimulate them. Obviously, the act of giving in individual situations any part of the confiscated property to them without any legal authorization (international or domestic) would constitute embezzlement in office by the public official in charge unless the justification of extreme necessity or permissive risk is applicable ${ }^{18}$.

2) Exceptionally, ad hoc agreements on international asset sharing might be reached as well. In general, they are based on the principle reciprocity between requesting and requested countries. However, the country which approaches other countries with requests for confiscation may rely on reciprocity with them if its domestic legal framework for international cooperation is of good quality and does not unreasonably prevent their incoming requests from being executed.

To avoid any such unreasonable prevention, CARA should be improved. This Act provides for confiscation of property found in the territory of RS if some serious crime (specified in Article 2 of the Act) was committed and ascertained by a local judgment-Article 28 in conjunction with Article 48(2) of the Act ${ }^{19}$. The problem is that CARA does not prescribe any confiscation if no such judgment is issuable because local criminal law is not applicable to the conditioning crime $^{20}$ at all. For this reason CARA is not well synchronized with the $1990 \mathrm{Eu}-$ ropean Convention on Laundering, Search, Seizure and Confiscation of the Proceeds from Crime, ETS 141 [in force for BiH since 01 July 2004]. The Convention virtually requires some domestic law "extension" for its actual implementation in all cases where confiscation is appropriate.

According to Article 13 of this Convention, "a Party, which has received a request made by another Party for confiscation concerning instrumentalities or proceeds, situated in its territory, shall: 1) enforce a confiscation order made by a court of a requesting Party in relation to such instrumentalities or proceeds; or 2) submit the request to its competent authorities for the purpose of obtaining an order of confiscation and, if such order is granted, enforce it". Further on,

${ }^{17}$ It might be appropriate to borrow the general idea of Article 20.6 of the Law of Azerbaijan on the Prevention of the Legalization of Criminally Obtained Funds and Other Property and the Financing of Terrorism: "...the funds or other property confiscated on the territory of the Republic of Azerbaijan may be fully or partially delivered to" the requesting country.

${ }^{18}$ Girginov (2016), p. 89.

${ }^{19}$ This Paragraph 2 reads: "Provided that there is no internationally reached agreement or that some of the issues had not been defined by international agreement, international cooperation is to be reached in accordance with the provisions presented by this Act".

${ }^{20}$ It is called "conditioning" as it opens the way to confiscation because the assets subject to confiscation are related to the crime (most often the link is causal: they originate from it) or because the owner is sentenced for the crime and is in possession of assets which are also confiscable on the grounds (Article 3.1 CARA) that are not explainable with his/her lawful income and are likely to originate from some other criminal activity. 
pursuant to Article 14 "the procedures for obtaining and enforcing the confiscation shall be governed by the law of the requested Party"; under Article 15, "Property confiscated by a Party..., shall be disposed of by that Party in accordance with its domestic law".

Obviously, the Convention makes no exception for cases when the requested country's criminal law is not applicable to the crime conditioning confiscation. Therefore, the Convention does not free on the grounds that national criminal law is inapplicable any requested country, incl. $\mathrm{BiH} / \mathrm{RS}$, from the obligation to confiscate at incoming international requests. The importance of such confiscation, even though conditioned by a crime the requested country's law cannot be applied to, is beyond doubt ${ }^{21}$.

It is true that if the assets wanted for confiscation are located in RS as a requested party, this usually is a clear indication of a money laundering crime committed in part, at least, in its territory. In theory, this place of commission makes the applicability of local criminal law inevitable. Hence, it seems that once RS authorities receive an international request for confiscation, they can institute own criminal proceedings for money laundering to obtain a local judgment ascertaining the commission of this crime and then proceed with the requested confiscation.

In practice, however, such money laundering is difficult to prove, let alone be ascertained by a local judgment. As a result, in almost all cases of incoming requests for confiscation conditioned by crimes, committed abroad to which RS criminal law is not applicable, its authorities would, inevitably, break the quoted Article 13 of the Convention. To avoid such systematic violations, counterproductive to local budget as well (see the quoted Article 15 of the Convention), CARA should provide for an additional confiscation procedure: triggered solely on the grounds of incoming international requests for confiscation when the conditioning crime does not fall within RS jurisdiction but has been ascertained, for example, by a judgment in the requesting country. Otherwise, foreign countries may always reciprocate by refusing to grant requests from $\mathrm{BiH}$ (RS) for confiscation, when their national criminal law is not applicable to the conditioning crime, even if-in contrast to $\mathrm{BiH}$ (RS) - such confiscation is allowed under their law.

Probably, some prosecutors and judges may try to construe expansively, even apply by analogy, CARA provisions which allow confiscation (Article 2 and 28, specifically) for the purpose of including in the confiscation grounds also the conditioning crimes committed abroad to which local criminal law is not applicable. This is hardly feasible though, especially given the general idea of the in dubio pro reo argument. Therefore, the positive result is likely to occur in few cases. A serious risk of a negative result would always exist.

Obviously, the lack of a clear provision allowing confiscation when the local criminal law is not applicable to the conditioning crime substantiates such a risk of failure. This risk created by legislative inaction cannot be justified since one ${ }^{21}$ Diligenski (2016), p. 563. 
simple legal text is sufficient to remove the risk and guarantee the success of confiscations conditioned by crimes beyond the scope of national criminal law ${ }^{22}$.

In the end, it is appropriate to note that e.g. Article 2.2 of the Law of Azerbaijan on the Prevention of the Legalization of Criminally Obtained Funds and Other Property and the Financing of Terrorism tried to offer an alternative solution to the problem with confiscation of assets when the criminal law of the requested country is not applicable to the conditioning crime and therefore, the crime is beyond the country's jurisdiction. This Paragraph reads: "This Law shall apply to the activities related to the legalization of the criminally obtained funds or other property and the financing of terrorism outside the jurisdiction of the Republic of Azerbaijan in accordance with the international instruments to which the Republic of Azerbaijan is a Party".

However, while focusing on conditioning crimes beyond own jurisdiction, the quoted legal text-similarly to Article 48(1) of CARA-relies only on international law. Such a legislative solution is hardly sufficient to yield a positive result since international law (Article 15 of the European Convention on Laundering, Search, Seizure and Confiscation of the Proceeds from Crime) postulates that the property subject to confiscation is disposed of by the requested country "in accordance with its domestic law". Hence, if the domestic law returns the issue to international law, the respective country creates a vicious circle [Latin: circulus vitiosus] only. To get out of this vicious circle the domestic law of the requested country should expressly regulate this issue by providing that even if the conditioning crime is beyond the criminal jurisdiction of the country, the property shall, nevertheless, be confiscated if all other legal requirements are met.

3) When it comes to the Federation of $\mathrm{BiH}$, the other entity of $\mathrm{BiH}$, one can argue that the applicability of own criminal law to the conditioning crime is not always necessary for confiscation on foreign requests. This is true in part since the applicability of the own criminal law to the conditioning crime is not necessary in cases when requested confiscation results from recognition and enforcement of foreign judgments, incl. those which contain also some confiscation order. Therefore, this confiscation is feasible as even the recognition of such foreign judgments does not require applicability of own (the requested and potentially executing country's) criminal law to the conditioning criminal offence. Once recognized, the foreign judgment is enforced together with confiscation order it contains. As per Article 37(2,3) of the Federation of BiH Law on Forfeiture of Criminal Proceeds:

"(2) The decisions of the competent authorities in Bosnia and Herzegovina, adopted on the basis of the Mutual Legal Assistance in Criminal Matters Law,

\footnotetext{
${ }^{22} \mathrm{As}$ far as it can be judged from $\mathrm{BiH}$, Macedonia, for example, faces the same problem. Article 27(1) of its 2010 Law on Judicial Cooperation in Criminal Matters postulates that confiscation requested by other countries shall be executed in conformity with the Criminal Code, the Criminal Procedure Code and international agreements. Obviously, national legal framework for such requested confiscation is necessary as internationalagreements refer to local laws regarding mechanisms of confiscation but none of the laws of Macedonia envisage the situations when the conditioning crime is beyond the reach of its local criminal law.
} 
which require temporary forfeiture or pecuniary gain..., shall be submitted to the Agency in the execution.

(3) The provisions of paragraph 2 of this article are applicable to decisions of the competent authorities in Bosnia and Herzegovina, which recognize and enforce foreign judgments, if these decisions contain a measure of forfeiture of property and proceeds of crime".

It follows that the confiscation measure within the judgment is executable in the requested country's territory even when its criminal law is not applicable to the offence. Per argumentum a contrario, in all other situations, where a foreign judgment is not enforced, no such a confiscation is possible even under the quoted Law, if own criminal law is not applicable to the conditioning offence. Two are these other typical situations where no foreign judgment is enforced but, nevertheless, confiscation should be carried out:

- when an executable foreign request for the enforcement of a separate confiscation order issued in the requesting country has been received, and

- when an executable foreign request for confiscation has been received without any confiscation order issued in the requesting country.

Both situations demanding confiscation are envisaged in Article 13 of the UNCATOC. Undoubtedly, the legislative implementation of this Article may not be limited only to cases where local criminal law is applicable to the crime conditioning confiscation. All this means that, like RS, the Federation of $\mathrm{BiH}$ has to produce a general rule allowing confiscation even when the conditioning crime is beyond own criminal jurisdiction.

4) $\mathrm{BiH}$ is neither a Party to the European Convention on the International Validity of Criminal Judgments, nor a Party to other European instruments for recognition and enforcement of foreign judicial acts/decisions (judgments, tndiorders). This should not be a long-lasting situation as the general tendency in Europe is to comply with and implement the underlying principle of MUTUAL RECOGNITION OF JUDICIAL DECISIONS ${ }^{23}$.

This principle cannot be avoided by $\mathrm{BiH}$ given its EU orientation. The said principle is reflected in Article 82(1)(i) of the 2012 Treaty of the Functioning of the European Union. This provision encourages the mutual recognition of sanctions (punishments and security measures) in the EU, incl. freezing and confiscation orders, and financial penalties-see the Council Framework Decision No. 2001/500/JHA on money laundering, the identification, tracing, freezing, seizing and confiscation of instrumentalities and the proceeds of crime, the Framework Decision No. 2003/577/JHA on the execution in the European Union of orders freezing property or evidence, the Framework Decision No. 2006/783/JHA on the application of the principle of mutual recognition to confiscation orders and the Framework Decision No. 2005/214/JHA on the application of the principle of mutual recognition to financial penalties.

In view of all this, it is recommendable that the $\mathrm{BiH}$ authorities consider becoming a Party to the European Convention on the International Validity of ${ }^{23}$ See Klimek (2017). 
Criminal Judgments (CETS 070). This is particularly necessary given Article 62(1)(i) of the BiH Law on Mutual Legal Assistance in Criminal Matters \{the MLA Law\}. It postulates that foreign criminal judgments are executed in $\mathrm{BiH}$ "only where so provided by international treaty".

\section{Exchange of Evidence for Confiscation of Assets}

1) Two types of international cooperation exist when the property subject to confiscation is in a foreign country: judicial cooperation in criminal cases and purely administrative procedure designed to ensure the confiscation of criminal assets. The judicial assistance consists predominantly of execution of letters rogatory. Their execution may result, inter alia, in collection and provision of evidence about the proceeds from the investigated crime. This evidence is usable to substantiate their confiscation as well.

The international administrative procedure is more common between administrative agencies rather than judiciaries. Most often, the cooperating administrative agencies are Financial Investigation Units. This international procedure is mentioned in a number of domestic laws of foreign countries governing criminal assets recovery through non-criminal legal proceedings, for example: the Serbian Law on Seizure and Confiscation of Proceeds from Crime (2008), the UK Proceeds of Crime Act (2002), etc. International assistance matters are also regulated in Articles 48-59 of CARA. However, it should always be remembered that the procedure is comparatively new and not well known. This is why many countries are hesitant and even reluctant to respond to requests under this procedure.

Moreover, some domestic laws on criminal assets recovery expressly postulate that this international cooperation is rendered solely on the basis of international agreements (e.g. Article 92 of the 2005 Bulgarian Law on the Forfeiture of Criminal Assets to the Exchequer). This makes the administrative requests even less reliable. Therefore, one should comply with the following recommendation: if some necessary information can be obtained through both, a letter rogatory and an administrative request, the former should be preferred to the latter.

Administrative requests are less reliable for another important reason as well. They do not guarantee that information can be obtained in case of bank secrecy. This does not apply to letters rogatory. On the contrary, they are the truly appropriate means to obtain such information. According to Article 7(5) of the 1988 UN Drug Convention and Article 18(8) of the UNCATOC, "Parties shall not decline to render mutual legal assistance ... on the ground of bank secrecy". Furthermore, all these conventions prescribe that mutual legal assistance ... may be requested for any of the following purposes: ...Providing originals or certified copies of relevant documents and records, including government, bank, financial, corporate or business records; identifying or tracing proceeds of crime, property, instrumentalities or other things for evidentiary purposes. Nothing of this sort has been provided for in favor of any administrative request relating to 
criminal assets and their confiscation.

2) Given the importance of letters rogatory, the channels of their transmission should be clarified. Since $\mathrm{BiH}$ exchanges a lot of evidence with EU countries, the reliability of the EUROJUST channel should be identified well. Usually, this channel is used in situations of urgency.

According to Article 4(4) of the MLA Law, "In urgent cases, requests for mutual legalassistance may be forwarded andreceived through Eurojust-the EuropeanUnion Agency for police ${ }^{24}$ and judicialcooperation in criminal matters". This domestic provision, however, does not produce the desired result; this makes it misleading. $\mathrm{BiH}$ authorities should resort to means that can actually produce the result in question.

EUROJUST serves EU Member States. They, plus $\mathrm{BiH}$ as well, are all Parties to the European Convention on Mutual Assistance in Criminal Matters \{ECMACM $\}$ and most of them-also to the Second Additional Protocol thereto as well. Hence, when it comes to transmission of any request, incl. requests in urgent cases and using Eurojust for this purpose if possible at all, these two Council of Europe $\{\mathrm{CoE}\}$ instruments are applicable, namely: their texts (Article 15 of the Convention, Article 4 of the Second Ad Prot) together with the declarations to them made by interested Parties. The transmission of requests in urgent cases is within their subject-matter, exclusively.

Given the priority of international agreements (Article 1.1 of the MLA Law), the provisions of the $\mathrm{CoE}$ instruments and the declarations to them are the sole means to determine communication channels, in general, and those to be used in urgent cases, in particular. Pursuant to Article $15\left(5 / 7^{25}\right)$ of ECMACM, INTERPOL isas a general rule this channel for all Parties. $\mathrm{BiH}$ is no exception since this country has not made any declaration for a different channel, incl. for using Eurojust. As a result, the quoted Article 4(4) of the Law mentioning the Eurojust channel is not applicable at all; its applicability is excluded by the aforementioned $\mathrm{CoE}$ instruments.

The texts of the CoE instruments and declarations thereto must be clearly distinguished from any domestic law on international legal assistance. They take precedence over any such law-Article 1(1) of the MLA Law. As the domestic law is of subsidiary legal force, it cannot serve as any substitute of such declarations. Domestic law can never produce what is achievable solely through declarations.

This is fully valid when it comes to transmission of requests for international legal assistance, in particular. Declarations are the irreplaceable means to establish a new/different regulation of their transmission. Domestic laws can neither add new rules to the CoE instruments, nor derogate their existing provisions. Only declarations and reservations to the $\mathrm{CoE}$ instruments have such powers

\footnotetext{
${ }^{24}$ The word "police" is redundant, the Agency is for judicial cooperation only. This is its correct name: “The European Union's Judicial Cooperation Unit”.

${ }^{25}$ Para 5 is applicable to Parties to the Convention only, while Para 7 is applicable to those countries which are Parties to the Second Additional Protocol as well.
} 
and can produce the desired effect: to establish a different channel of communication.

This is why e.g. France, in order to recognize Eurojust as a channel through which it may be approached with requests, has submitted a Declaration [contained in the instrument of ratification deposited on 6/02/2012] to Second Additional Protocol to the ECMACM that requests for international legal assistance "may also ... be forwarded through the intermediary of the French national member of the Eurojust judicial co-operation unit'.

A similar declaration by $\mathrm{BiH}$ to the ECMACM is necessary. Otherwise, $\mathrm{BiH}$ authorities cannot safely accept Eurojust as a communication channel through which to be approached by other Parties to the ECMACM with requests for international legal assistance. This is because no domestic law in $\mathrm{BiH}$, incl. Article 4(4) of the MLA Law, has the legal power to regulate issues that fall within the subject-matter of $\mathrm{CoE}$ instruments.

It is worth clarifying that the text of Article 4(4) of the MLA Law cannot be transformed in full into the necessary Bosnian declaration to the ECMACM. The first part of this text, in particular, is not transformable. It postulates that $\mathrm{BiH}$ judicial authorities may forward requests to other Parties to the Convention through EUROJUST. Yet, $\mathrm{BiH}$ is not in the position to impose obligations on foreign countries regarding the communication channels through which they should receive requests. Hence, $\mathrm{BiH}$ cannot make other Parties accept EUROJUST, in particular, as a channel through which to receive Bosnian requests. It is up to each Party to decide individually as to whether it may be approached through EUROJUST with any request. Until a given Party recognizes EUROJUST as such a channel, $\mathrm{BiH}$ is not authorized to turn to this Party through EUROJUST. Bosnian authorities cannot change anything unilaterally: by its MLA Law or even by a declaration to the ECMACM. If a prosecutor or a judge from $\mathrm{BiH}$ disregards the lack of such authorization to approach another Party through EUROJUST with a letter rogatory, then even if that Party executes it, the judicial validity of the evidence obtained in this way would, nevertheless, be highly disputable. Imprecise executions inspired by requesting countries are not uncommon; they are carried out by requested countries as, in general, such countries are not interested in the result.

In short, the declaring Party cannot make other Parties assume some conduct. It can only explain its own mechanism of work to them ${ }^{26}$. It follows after all that $\mathrm{BiH}$ is in the position to solely declare that it is ready to receive requests from

\footnotetext{
${ }^{26}$ Another negative example in this respect is Ukraine with its declaration of 12 October 2015 to the ECMACM that this Party cannot execute requests in the territories occupied by Russia, namely: the Crimean peninsula and the regions and Donetsk and Lugansk. Further in the declaration, Ukraine states that any execution of incoming requests by occupying Russian authorities there can have no legal effect. Thus, the evidence produced is inadmissible in the requesting Parties, if it comes from Russian authorities. Obviously, this second part of the declaration oversteps the role of any declaration. No declaration can prescribe to any requesting Party how to evaluate evidence obtained from the territories of declaring Parties. Therefore, only the first part of the Ukrainian declaration, referring to own capacities, is acceptable and worth taking into consideration.
} 
other Parties through EUROJUST. Therefore, only the second part of Article $4(4)$ of the MLA Law is transformable into the necessary Bosnian declaration to the ECMACM.

Besides, should the example of France be closely followed, the declaration is expected to specify the Bosnian addressee of requests forwarded to $\mathrm{BiH}$ through EUROJUST. The likely choice is the $\mathrm{BiH}$ Ministry of Justice contact point for EUROJUST. This is the feasible solution because the BiH Ministry of Justice is the only body not restricted to one of the four Criminal Codes operating in $\mathrm{BiH}$. This Ministry serves proceedings for all crimes to which criminal laws in $\mathrm{BiH}$ are applicable and can, in turn, adequately process all incoming requests regardless of the nature of the crime in respect of which assistance is requested.

3) The authorities of $\mathrm{BiH}$ and EUROJUST have been considering signing of a bilateral agreement to regulate their joint work in the field of evidence exchange and other modalities of international judicial cooperation ${ }^{27}$. With such an agreement, both Parties are likely to face a similar problem. As in the case with the Law and its Article 4(4), this agreement might be also of subsidiary legal nature only. Like the MLA Law, it cannot become any part of the ECMACM and therefore, cannot substitute the aforementioned declaration to this primary international instrument.

According to Article 26 (1-3) of the ECMACM, "this Convention shall, in respect of those countries to which it applies, supersede the provisions of any treaties, conventions or bilateral agreements governing mutual assistance in criminal matters between any two Contracting Parties. This Convention shall not affect obligations incurred under the terms of any other bilateral or multilateral international convention which contains or may contain clauses governing specific aspects of mutual assistance in a given field. The Contracting Parties may conclude between themselves bilateral or multilateral agreements on mutual assistance in criminal matters only in order to supplement the provisions".

Therefore, bilateral treaties, although concerning only two Parties, do not exclude the applicability of any of the two multilateral Conventions, pursuant to the legal maxim "lex specialis derogatlegi generali" ${ }^{28}$. Actually, bilateral treaties are subsidiary to the Convention rather than special to it. Hence, the position of any of the Convention is of a primary legal instrument.

Certainly, Article 26 of the ECMACM envisages expressly direct agreements (bi- or multilateral) between its Parties. It does not deal with any agreement between a given Party and some intermediary agency acting on behalf of several Parties to the Convention. EUROJUST [The European Union's Judicial Cooperation Unit] is such an agency: it would act in regard to $\mathrm{BiH}$ on behalf of these Parties to the Convention which belong to the European Union. In this sense, EUROJUST appears as an extension of the competent central authorities ${ }^{27}$ From http://www.mpr.gov.ba/aktuelnosti/vijesti/default.aspx?id=6055\&langTag=en-US, accessed on 13 April 2017.

${ }^{28}$ See also Akehurst (1975), p. 273. 
of EU countries with regard to third countries ${ }^{29}$.

Such an intermediary hardly changes the situation with third European countries in such a way to undermine the priority of the ECMACM. It would be much clearer and safer for all evidence requested and transmitted through EUROJUST, if this priority stays.

Moreover, it would be recommendable that the future agreement between $\mathrm{BiH}$ and EUROJUST should contain a provision recognizing the priority of the Convention. Article 118 of the 2002 Chisinau Convention of the Commonwealth of Independent States [most of the former Soviet Union countries] on Legal Assistance and Legal Relations in Civil, Family and Criminal Matters might be an appropriate example to follow. This Article postulates that "the Contracting Parties which are also parties to one or several Council of Europe conventions in the penal field, containing provisions affecting the subject matter of this Convention, shall apply only those provisions which complement these Council of Europe Conventions or facilitate the application of the principles contained therein".

4) Lastly, international legal assistance plays an important role in the confiscation of criminal assets. However, the role of this assistance should not be overestimated. Even letters rogatory for delivery of physical items cannot directly serve their confiscation (permanent seizure and disposal).

The $\mathrm{BiH}$ legislator has accepted, more or less, the contrary view in Article 20(1) of the MLA Law. This provision envisages execution by BiH of incoming requests for delivery of items. It reads that "The articles or property gain that have been temporarilyseized for the purpose oftheir protection may be handed over to a foreign judicial authority, at their request, following the completion of the mutual legal assistance proceedings, for the purpose ofseizure or in order to return them to an authorized person". The first option in the text means that the requesting foreign judicial authority retains "for the purpose of seizure" items handed over by $\mathrm{BiH}$. This option is not realistic, though. If $\mathrm{BiH}$ has delivered some item to a requesting country and this item is subject to confiscation (permanent seizure and disposal), that foreign country shall give the item back to $\mathrm{BiH}$ as soon as the need of it ceases to exist.

The requesting country does not retain any item for the purpose of its confiscation. This is because no such retention by a requesting country may support confiscation (permanent seizure and disposal). Actually, the described retention of an item, rather than giving it back, is a possible situation but it refers only to cases when the item shall not be confiscated at all. Instead, it must be returned to an authorized person in the requesting country, as the second option in Article 20(1) of the MLA Law reads correctly. Such a person might be its legitimate owner from the requesting country, pursuant to Article 57(3)(a) or (b) of the UNCAC, or other rightful and undisputed possessor who resides, for some exceptional reason, in the territory of that requesting country. Otherwise, if the

${ }^{29}$ See http://www.eurojust.europa.eu/Pages/home.aspx, accessed on 14 April 2017. 
possessor is not there, as s/he normally is in $\mathrm{BiH}$ since the item has been taken from him/her here, this item shall be given back to $\mathrm{BiH}$ as the requested country. Then $\mathrm{BiH}$ should decide on handing the item over to the possessor.

The same applies to cases when some dispute over the possession of the item exists. As this possession and the dispute over it occur in $\mathrm{BiH}$ and no execution of any request in criminal matters can change the possession since it is a civil (property law) issue, the dispute shall be solved here, by the court of the possessor's location.

However, when it comes to actual confiscation (seizure and disposal) of items rather than their return to authorized persons, the mechanism under Article20, Paragraph 1 of the MLA Law is not applicable. Actually, this mechanism, starting with retention by the requesting country of the item handed over to it, has nothing to do with confiscation at all.

If requested by means of a letter rogatory, the items are delivered to the requesting country solely as physical evidence and once they are not needed any longer for the respective proceedings there, these items shall be returned to $\mathrm{BiH}$ as the requested country. Given its right to dispose of them under its law (Article 15 the European Convention on Laundering, Search, Seizure and Confiscation of the Proceeds from Crime), no requested country, incl. $\mathrm{BiH}$, is expected to waive the return, as provided for in Article 6(2)(ii) of ECMACM, for example.

Even if asset sharing is mandatory, the entitled requesting country would not be given any piece of the item. That country would receive a financial compensation by transferring a sum of money to it. Understandably, the compensation would be equal to that country's share under applicable law or the ad hoc agreement with the requested country.

It follows that no foreign country can retain for the purpose of confiscation (permanent seizure and disposal) items delivered by BiH. This makes the first part of Article 20(1) of the MLA Law inapplicable and misleading. Therefore, only the second part of the Paragraph is accurate and should stay. The second part is to be deleted. As a result, Article 20(1) of the MLA Law would read:

"The articles or property gain that have been temporarily seized for the purpose of their protection may be handed over to a foreign judicial authority, at their request, following the completion of the mutual legal assistance proceedings, in order to return them to an authorized person who resides in the foreign country's territory. Otherwise, the items are delivered temporarily, until needed for the respective proceedings in the foreign country".

\section{Conclusion}

The present legislative review substantiates several essential recommendations to the authorities of $\mathrm{BiH}$ and its two entities:

- Create a domestic rule on international sharing of crime-conditioned assets.

- Create a general domestic rule making it possible to confiscate on foreign requests crime-conditioned assets (not only on the basis of recognition and 
enforcement of a foreign judgment but always) when the conditioning crime is beyond the applicability of the local criminal law. The procedures prescribed in the same law are to be followed.

- Reconsider the appropriateness of the phrase "gain which has been obtained directly or indirectly from the crime", in the text of Article 3(1), "a" of the RS Criminal Assets Recovery Act.

- Consider becoming a Party to the European Convention on the International Validity of Criminal Judgments.

- Prepare and submit a declaration to European Convention on Mutual Assistance in Criminal Matters and the Second Additional Protocol thereto reproducing the second part of Article 4(4) of the BiH Law on Mutual Legal Assistance in Criminal Matters.

- Modify the text of Article 20 of the MLA Law to make it compatible with actual mutual legal assistance in support of seizure of items liable to confiscation.

\section{References}

Akehurst, M. (1975). The Hierarchy of the Sources of International Law. British Yearbook of International Law, 47.

Diligenski, T. (2016). The Influence of the EU on Designing of Anti-Corruption Policy. “ARCHIBALD REISS DAYS” Thematic Conference Proceedings, Belgrade: Academy of Criminalistics and Police Studies.

Girginov, A. (2016). Justified Risk and Extreme Necessity in the Criminal Law of Bosnia and Herzegovina (Lex Ferenda). Proceedings of the Faculty of Law, University of Travnik, $\mathrm{BiH}$.

Ненов, И. (1992). Наказателно право на Република България. Обща част. Кн. 2, София.

Klimek, L. (2017). Mutual Recognition of Judicial Decisions in European Criminal Law. Springer. https://doi.org/10.1007/978-3-319-44377-5

Miljko, Z. (2006). Ustavnouređenje Bosnei Hercegovine. Zagreb: Hrvatskasve-učilišnanaklada.

Turone, G. (2006). Legal Frameworks and Investigative Tools for Combating Organized Transnational Crime in the Italian Experience. 134th International Training Course Visiting Experts' Papers, UNAFEI, Resource Material Series, No. 73, 48. http://www.unafei.or.jp/english/pdf/RS_No73/No73_10VE_Turone.pdf 
Submit or recommend next manuscript to SCIRP and we will provide best service for you:

Accepting pre-submission inquiries through Email, Facebook, LinkedIn, Twitter, etc. A wide selection of journals (inclusive of 9 subjects, more than 200 journals)

Providing 24-hour high-quality service

User-friendly online submission system

Fair and swift peer-review system

Efficient typesetting and proofreading procedure

Display of the result of downloads and visits, as well as the number of cited articles Maximum dissemination of your research work

Submit your manuscript at: http://papersubmission.scirp.org/

Or contact blr@scirp.org 